\title{
Special Section Editorial: Russell Messier's Lifetime of Nanomorphology
}

\author{
Akhlesh Lakhtakia \\ Nanoengineered Metamaterials Group, Department of Engineering Science and Mechanics, \\ Pennsylvania State University, University Park, Pennsylvania 16802, USA \\ akhlesh@psu.edu
}

This Special Section of the Journal of Nanophotonics on nanomorphology comprises papers written by friends, colleagues, and former students of Russell Messier, Professor Emeritus of Engineering Science and Mechanics at the Pennsylvania State University, to commemorate his $65^{\text {th }}$ birthday.

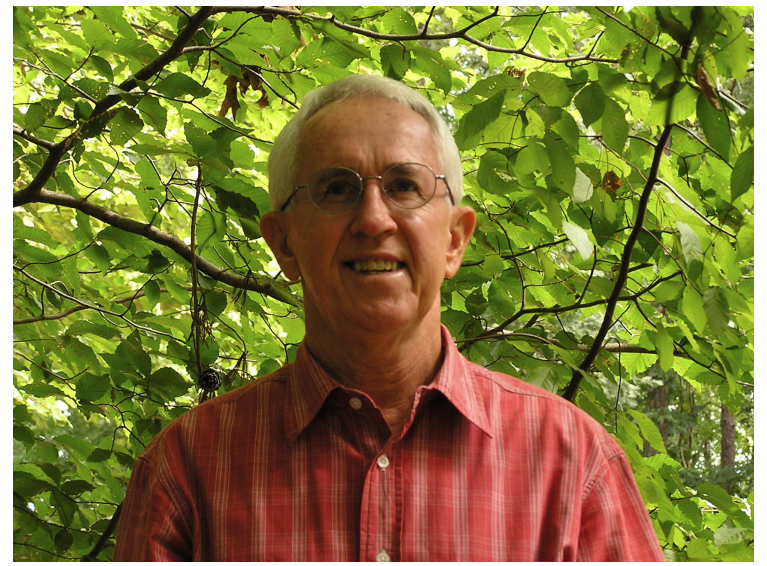

Fig. 1. Russ Messier: 64 years young and golfing as often as he can these days.

\section{RUSS MESSIER}

Let me introduce you to my friend, colleague, and mentor, Russell Francis Messier, who prefers to omit his middle name for some reason. He prefers to be called Russ. One look at him, and you will agree that he is definitely a Russ. Not only a Russ, but he is a New-England Russ, as you will quickly guess from his pronunciation: when he calls out to his lovely wife Linda, Linder comes out of his mouth.

Russ was born on July 30,1944, into a working-class family with no history of formal education beyond high school. His father made shoes at a local factory and his mother did piecework for Sprague Electric. While growing up in southern New Hampshire, his childhood was typical of middle-class America at that time. He spent lots of time outdoors, playing games and sports and socializing, with ample time to simply lie down on the grass and look into the sky and fantasize about where he came from and where he wanted to go.

Mathematics and science came easily and enjoyably, but baseball, basketball, soccer, and golf were his focus. Soccer, especially, taught him many life lessons, those of dedication, hard work, and teamwork leading to success in many different ways. During three years on his high-school's premier soccer team, the last as a co-captain, his school came in third, first, and second, successively, in the New Hampshire state championships. But golf was, and remains, 
his major passion, with winning the British Open his teenage dream. (After retirement, he has resumed golfing and hopes to become a "phenom" on the veteran's circuit.) Work was always part of the mix: picking up trash at a local fried-clam stand at 5:30 am, delivering newspapers in the afternoon, and caddying most every day throughout his teenage years.

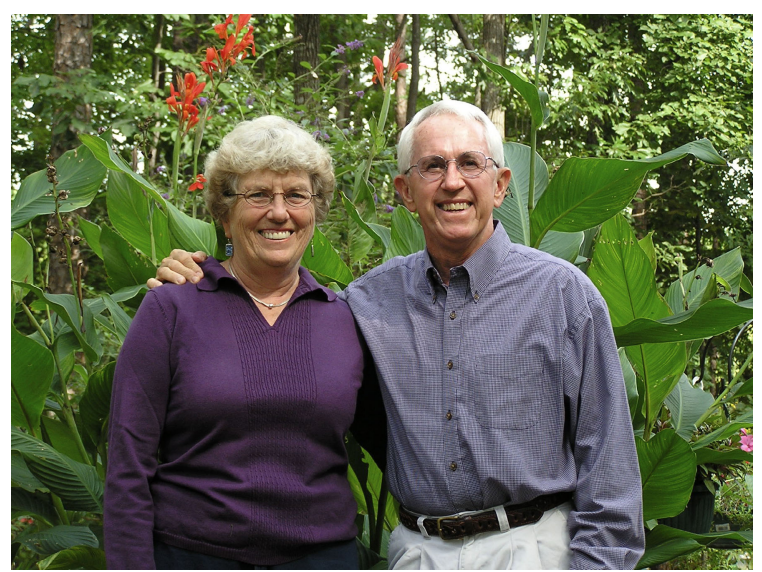

Fig. 2. Linda and Russ Messier in Linda's garden.

The era of Sputnik emerged while Russ was in high school. Its influence was to direct him towards engineering and education as an immediate life goal. Being a statistical realist, he realized that professional golf was not his future route to the American dream of that time- to do better than your parents by going to college and fulfilling both their dreams and yours.

Northeastern University was a blue-collar university in Boston, with a good reputation in engineering and, most importantly, was, and still is, the largest co-operative education school in the nation. With money in Russ' family always in short supply, the co-op work experience was of more immediate value than providing the route to his career in materials research. Between scholarships, his savings from his teenage work, and his co-op wages, his parents' total cost for his college education was $\$ 500$ plus room and board while on his work assignments.

A co-op assignment took him to Sanders Associates, an early microelectronics company in Nashua, New Hampshire. He had the good fortune of working in the applied physics research laboratory at Sanders off and on for three years. This laboratory was then developing highfrequency delay lines and transducers for military electronic-countermeasure systems. He started out polishing crystals of cadmium sulfide to thinner and thinner dimensions in order to achieve higher and higher operating frequencies. The relentless demand for even higher frequencies drove him from a top-down approach (polishing) to a bottom-up approach (thinfilm deposition). This was the beginning of his work in the nano-world of thin-film science and technology. By this time shoe-manufacturing jobs had disappeared from the American workplace, an early victim to cheaper foreign labor, and his father was now working at Sanders as a technician. Russ has a bittersweet memory during his junior year when he returned to his co-op job and found out he was earning more than his father-a consequence of education and opportunity. It was a proud moment for his parents.

By the time Russ graduated from Northeastern in 1967 with a BS degree in electrical engineering, he realized that materials science was his career passion and, although his training in electrical engineering provided a wonderful base, education at a graduate school was essential. After considering Rensselaer Polytechnic Institute, the University of Rochester, Johns Hopkins University, and Penn State, Russ made the life-defining decision to go to Penn State and to carry out his research in one of the new Materials Research Laboratories (MRL) funded by the National Science Foundation. Prof. Rustum Roy, then the director of MRL, 
became his thesis advisor. He also gave Russ the opportunity to go in a direction that was new for MRL: deposition of thin films of new materials using new plasma-based technologies. Radiofrequency sputtering became a commercial reality in 1967, and Russ ended up with the first rf-sputter deposition system made by the Materials Research Corporation. That system was used as a demonstration model in 1968. It allowed Russ to explore the nano-world of thin films with the use of concurrent ion bombardment during film growth, an aspect covered in his paper in this special section.

During his years as a graduate student, Russ was neither a bookworm nor a lab freak. His life headed in several directions besides research: "preparation for later life," as he would say afterwards. By the spring of 1968, he was elected president of the Graduate Student Association at Penn State. Those were tumultuous times for student activism on American college campuses. For the next year his days weren't long enough, being torn between classes and research in one direction and campus politics, protests, and social events in the other direction. Yet he found time to nurture his relation with the chair of his social committee, a Spanish major and friend. Linda O'Brien became his wife by the time his presidency, though not his involvement, came to an end. That was 39 years, two children, and four grandchildren ago. And their love for one another is still going strong.

After receiving his $\mathrm{PhD}$ degree in 1973 in solid-state science, an interdisciplinary program in materials, and continuing his research as a postdoctoral scholar for an additional year, Russ left Penn State to pursue a different area of research: development of phosphor powders for medical x-ray technology. However, his interest in thin-film science was not quenched, and he returned to Penn State to pursue this career direction. Starting with a year-to-year contract position in 1976, his career in materials research flourished with funding initially in the solarenergy materials area and then on thin-film morphology.

Funding from the U.S. Air Force Office of Scientific Research from 1982 to 1985 focused and consolidated his work on thin-film morphology. During that period, I met Russ. He was then a senior research associate at MRL and also an associate professor of solid-state science. I was a research associate in the Department of Engineering Science and Mechanics. We met in the office of a senior colleague, perhaps in August 1984. Russ began telling us about fractals and the fractal morphology of thin films. He showed us top-surface and crosssectional scanning electron micrographs of various types of thin films. He showed us a thick sample of pyrolytic graphite. I knew nothing about fractals then. I had heard about scanning electron microscopes, but had not seen micrographs earlier. Russ was very patient. Thereafter, we met several times.

A year passed. One day, a 1000-W lamp turned on in my brain, when I reacquainted myself with Dr. Seuss' The Cat in the Hat Comes Back. "Ah! So that's what a fractal is," I said to myself. Russ agreed, when I called him. Thereafter, we co-authored several papers on the Sierpinski gasket and other fractal structures. Along with Joe Yehoda, then a PhD student of Russ, we also grew wild-type cauliflowers in order to find their fractal dimension.

Richard McNitt, then the head of my department, offered a tenure-track appointment to Russ in 1985. Russ was tenured in 1986. Four years later, Russ was promoted to professor of engineering science and mechanics. Retiring in 2005, he was given the emeritus rank.

In 1988, Juan-Manuel García-Ruiz came to visit MRL for a year from Spain, to work with Heinz Henisch at MRL. Juan-Manuel, Russ, and I formed a discussion group. We met a couple of times a month, to chat about thin films and their morphology. Our big question was as follows: If thin films have a fractal morphology, why does matter at the length scales of everyday experiences form objects with Euclidean morphology? At one of these meetings, we suddenly realized competition between growth elements, both processes and material particles, is responsible for that transition. A paper was published by us some years later, and led directly to the conceptualization of sculptured thin films shortly thereafter.

By this time, Russ had become very famous for low-temperature diamond coatings. $\mathrm{He}$ made the first page of the September 14, 1986, issue of the New York Times. His grinning 
visage showed up in the cover story of the Money section of USA Today on March 18, 1987; perhaps, that was the reason for the Dow Jones Index soaring that day. Numerous other newspapers and magazines featured reports on this work. Russ went on to make distinguished contributions to the deposition and the characterization of ultrahard coatings and founded the first, and perhaps still the only, journal dedicated to that topic.

The morphology of thin films remained Russ' true passion throughout his academic career at Penn State. His dedication and contributions were recognized by the Leroy Randall Grumman Medal of the Grumman Corporation in 1987 and by the Fellowship of the American Vacuum Society in 1996. The Penn State Engineering Society gave him an Outstanding Research Award in 1990. His name figures in the ISI List of Highly Cited Researchers.

Lest it be construed that Russ is only a brilliant researcher, let me note that he oversaw undergraduate education in the Department of Engineering Science and Mechanics at Penn State for three years ending in 2005. During this period, he was so popular with undergraduate students that the Penn State Engineering Society gave him an Outstanding Advising Award in 2004

Throughout his career Russ was a natural mentor. More than a dozen visiting researchers from Taiwan, Spain, Germany, Mexico, Japan, and India have profited from his readiness to impart both information and knowledge to anybody at any time of the day (or, even the night, as Linda would add). A dozen junior faculty members have been mentored by him as well. There is no counting the number of graduate students whom he mentored: some were his own, others adopted him an unofficial research advisor. Thanksgiving and Christmas meals at the house of Russ and Linda and their two children, Stephen and Tamara ("Tammy"), would resemble a mini-meeting of the United Nations. Several graduate students in financial distress simply stayed with Russ and Linda until better times came. No wonder, Penn State conferred on him the Howard B. Palmer Mentoring Award in 2003.

Now that Russ and Linda have crossed the Mason-Dixon Line to live in Virginia, Russ is occupied with golfing and occasionally helping Linda in her garden. Both are doting grandparents to two dashingly handsome little boys and two breathtakingly beautiful little girls. The Messiers' absence at Penn State is acutely felt by his colleagues. Fortunately, telephones and the Internet lessen the distance between the two locations. Also, Russ and Linda often visit Penn State.

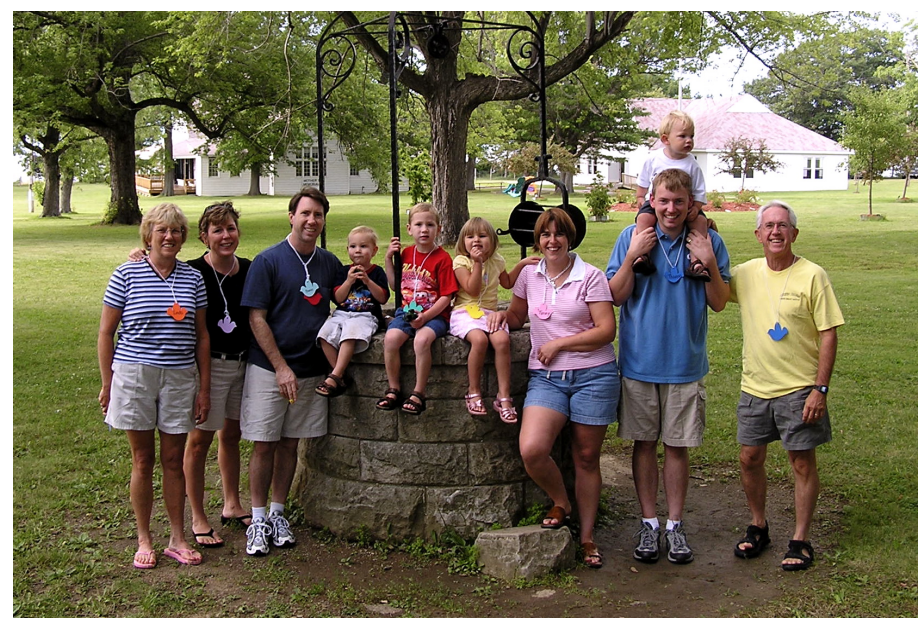

Fig. 3. Linda and Russ Messier with their two children, their children's spouses, and their four grandchildren. 


\section{NANOMORPHOLOGY}

Russ is widely known and admired for elucidation of the nanoscale morphology of thin films prepared by vapor deposition under low-adatom-mobility conditions, especially clustering at the sub-5-nm level. Over a career spanning four decades, Russ has examined all aspects of vapor-deposited nanomaterials and the evolution of their morphology from the nanoscale to the microscale. He has examined and developed various thin-film deposition processes ranging from physical vapor deposition to chemical vapor deposition techniques, and the morphologies produced by alterations of deposition conditions. He has focused on the translation of fundamental knowledge of morphology toward the manufacturing of useful thin-film materials. The culmination of the first three decades of his research can be appreciated by his wide-ranging contributions to (i) the science and technology of diamond, cubic boron nitride, and related ultrahard materials, and (ii) the emergence of sculptured thin films.

Research on thin-film materials became his focus, when as an undergraduate student he interned at Sanders Associates in the area of ultrasonic dielectric materials prepared by evaporation techniques. His graduate research at MRL expanded his thin-film preparatory methods to radiofrequency sputtering, an emerging field at the end of the 1960s, which allowed for the study of a wide range of insulating and semiconducting materials at much lower temperatures than their melting points. This led naturally to his $\mathrm{PhD}$ thesis on a new approach to understanding the formation of noncrystalline solids during which he developed an approach to preparing and understanding the continuum of free-energy states ranging from amorphous to nanocrystalline to microcrystalline to single crystal.

After two and a half years in industry in research on bulk luminescent materials, he returned to Penn State to continue research on thin-film materials. The ability to engineer their properties, and to make new materials, defined much of his subsequent research. By the early 1980 s, his work was revealing the commonality of film morphology independent of the material and dependent primarily upon the substrate temperature and ion bombardment during deposition. His 1984 paper on the evolutionary structure zone model of thin films prepared under low-adatom-mobility conditions is a seminal contribution to our understanding of columnar thin-film morphology. With a fractal-like conceptual and theoretical model in his mind, Russ used various microscopy techniques to connect the columnar morphology of thin films, prepared under low-adatom-mobility conditions, from the nanometer scale to the micrometer scale. His morphological studies of thin films prepared at temperatures about $0.3-$ 0.5 of the bulk melting point (in Kelvin), demonstrated that 1-to-3-nm clusters are the building blocks of an evolving surface morphology and the related internal void network. The effects, and quantification, of concurrent ion bombardment on the nanoscale and microscale morphology were also demonstrated for the first time. Extensive preparation and characterization studies of films provided the experimental database needed to develop and test the evolutionary zone model. Not surprisingly, he became the leading proponent of the importance of the quantification of thin-film morphology as a critical step in quantitative preparation-property relations.

Russ' expertise on morphology led me to call him in 1992, after I came across a sample of ulexite. Within a few weeks, we had developed a conceptual understanding of dynamically modifying the shapes of the growing columns (or nanowires) in a columnar thin film. When that understanding was reduced to practice in collaboration with colleagues at the University of Alberta, we enunciated the concept of sculptured thin films for optical, chemical, biological, and other applications. Many optical and some other applications have been realized since then, and more than 25 research groups worldwide are actively working on sculptured thin films today.

While his research on nanoscale morphology was in full swing, Russ also became the leader of a major group effort at Penn State on diamond films prepared by vapor deposition 
processes. This was the first group in the U.S. to recognize the importance of work begun in the USSR and Japan in the early 1980s. In 1985 his group repeated that work and published their first results. Since then, they have generated a large amount of scientific and even public interest through both government- and industry-funded research. Russ became the founding Editor-in-Chief of the international journal Diamond and Related Materials, serving in that position for about 15 years. From artificial diamonds to cubic boron nitride, a superhard material similar to diamond, was but a short step for Russ who went on to establish the bombardment stabilization of this metastable phase.

I would be remiss if I did not tell you that Russ is the discoverer of the explosive crystallization phenomenon in amorphous germanium and related thin films, which were used extensively in the late 1970s and early 1980s to study laser recrystallization of semiconductor films. Russ was also the first to demonstrate a high $T_{c}(13.7 \mathrm{~K})$ in thin-film ceramic superconductors with the perovskite structure. These were the precursor to the current wave of $90-\mathrm{K}$ perovskite high-temperature superconductors. He elucidated negative-ion resputtering in oxide-sputtering processes and the anisotropically etched morphology that results from that resputtering.

\section{PRINCIPAL PUBLICATIONS OF RUSS MESSIER}

The concluding section of this editorial is a list of the principal publications of Russ Messier. $\mathrm{He}$ is also named as an inventor or co-inventor on seven U.S. patents.

[1] R. Messier and R. Roy, "Thermal behavior of non-crystalline sputtered films in the system Ge-Te," Mater. Res. Bull. 6, 749-758 (1971) [doi:10.1016/00255408(71)90109-7].

[2] R. Messier, T. Takamori, and R. Roy, "Structural differences among different GeTe phases," J. Non-Cryst. Solids 8-10, 816-822 (1972) [doi:10.1016/00223093(72)90232-3].

[3] T. Takamori, R. Messier, and R. Roy, "New non-crystalline germanium which crystallizes "explosively" at room temperature," Appl. Phys. Lett. 20, 201-203 (1972) [doi:10.1063/1.1654108].

[4] T. Takamori, R. Messier, and R. Roy, "Phenomenology of the "explosive" crystallization of sputtered non-crystalline germanium films," J. Mater. Sci. 8, 1809-1816 (1973) [doi:10.1007/BF02403534]

[5] T. Takamori, R. Messier, and R. Roy, "Triboluminescence on "explosive" crystallization of non-crystalline germanium films," J. Mater. Sci. 9, 159-160 (1974) [doi:10.1007/ BF00554769].

[6] R. Messier, A. K. Sarkar, and R. Roy, "New metal-rich germanide and carbide non-crystalline solids," Mater. Res. Bull. 9, 157-166 (1974) [doi:10.1016/00255408(74)90195-0].

[7] R. Messier, T. Takamori, and R. Roy, "Observations on the "explosive" crystallization of non-crystalline Ge," Solid State Commun. 16, 311-314 (1975) [doi:10.1016/0038-1098(75)90175-1].

[8] R. Roy, P. F. Carcia, R. Messier, and D. Rogowski, "The effect of composition on the superconducting transition temperature in $\mathrm{NbN}_{\mathrm{x}} \mathrm{O}_{\mathrm{y}}$," Mater. Res. Bull. 10, 379382 (1975) [doi:10.1016/0025-5408(75)90008-2].

[9] R. Messier, T. Takamori, and R. Roy, "Structure-composition variation in rfsputtered films of Ge caused by process parameter changes," J. Vac. Sci. Technol. 13, 1060-1065 (1976) [doi:10.1116/1.569060]. 
[10] R. Messier and R. Roy, "RF-sputtered Fe-O films: Vapor species control in noncrystalline solid formation," J. Non-Cryst. Solids 28, 107-121 (1978) [doi:10.1016/0022-3093(78)90078-9].

[11] I. S. T. Tsong, C. A. Houser, N. A. Yusef, R. F. Messier, W. B. White, and J. W. Michels, "Obsidian hydration profiles measured by sputter-induced optical emission," Science 201, 339-341 (1978) [doi:10.1126/science.201.4353.339].

[12] L. R. Gilbert, R. Messier, and R. Roy, "Superconducting $\mathrm{BaPb}_{1-\mathrm{x}} \mathrm{Bi}_{\mathrm{x}} \mathrm{O}_{3}$ ceramic films prepared by R.F. sputtering," Thin Solid Films 54, 129-136 (1978) [doi:10.1016/0040-6090(78)90283-3].

[13] L. R. Gilbert, R. Messier, and R. Roy, "Black germanium solar selective absorber surfaces," Thin Solid Films 54, 149-157 (1978) [doi:10.1016/00406090(78)90191-8].

[14] S. V. Krishnaswamy, R. Messier, Y. S. Ng, and T. T. Tsong, "Thin film characterization by atom probe field ion microscopy," Appl. Phys. Lett. 35, 870872 (1979) [doi:10.1063/1.90988].

[15] L. A. Marusak and R. Messier, "Mössbauer and magnetic study of rf-sputtered $\mathrm{Fe}_{2} \mathrm{O}_{3}$ films," J. Appl. Phys. 50, 7630-7632 (1979) [doi:10.1063/1.326867].

[16] S. V. Krishnaswamy, R. Messier, Y. S. Ng, T. T. Tsong, and S. B. McLane, "Atom probe FIM investigation of voids in a-Ge," J. Non-Cryst. Solids 35-36, 531-536 (1980) [doi:10.1016/0022-3093(80)90649-3].

[17] S. V. Krishnaswamy, R. Messier, Y. S. Ng and T. T. Tsong, "Atom probe FIM-A thin film characterization technique," J. Vac. Sci. Technol. 17, $63-64$ (1980) [doi:10.1116/ 1.570505].

[18] D. M. Fell, L. L. Tongson, S. V. Krishnaswamy, R. Messier, and I. S. T. Tsong, "Characterization of commercial black chrome coatings," J. Vac. Sci. Technol. 17, 358-361 (1980) [doi:10.1116/1.570387].

[19] P. Swab, S. V. Krishnaswamy, and R. Messier, "Characterization of black Ge solar selective absorbers," J. Vac. Sci. Technol. 17, 362-365 (1980) [doi:10.1116/1.570388].

[20] L. R. Gilbert, R. Messier, and S. V. Krishnaswamy, "Resputtering effects in $\mathrm{Ba}(\mathrm{Pb}, \mathrm{Bi}) \mathrm{O}_{3}$ perovskites," J. Vac. Sci. Technol. 17, 389-391 (1980) [doi:10.1116/1.570397].

[21] R. Messier, S. V. Krishnaswamy, L. R. Gilbert, and P. Swab, "Black a-Si solar selective absorber surfaces," J. Appl. Phys. 51, 1611-1614 (1980) [doi:10.1063/1.327764].

[22] L. A. Marusak, R. Messier, and W. B. White, "Optical absorption spectrum of hematite, a- $\mathrm{Fe}_{2} \mathrm{O}_{3}$ near IR to UV," J. Phys. Chem. Solids 41, 981-984 (1980) [doi:10.1016/0022-3697(80)90105-5].

[23] J. S. Lannin and R. Messier, "Low-frequency modes in amorphous boron-rich alloys," Phys. Rev. Lett. 45, 1119-1122 (1980) [doi:10.1103/PhysRevLett.45.1119].

[24] C. Lo, S. V. Krishnaswamy, K. R. P. M. Rao, R. Messier, and L. N. Mulay, "Synthesis of iron-nitrogen compounds by r.f. sputtering: Mossbauer studies," Mater. Res. Bull. 15, 1267-1272 (1980) [doi:10.1016/0025-5408(80)90030-6].

[25] S. V. Krishnaswamy, R. Messier, S. B. McLane, Y. S. Ng, and T. T. Tsong, "Cluster formation in amorphous and polycrystalline thin films," Thin Solid Films 79, 21-26 (1981) [doi:10.1016/0040-6090(81)90424-7].

[26] S. V. Krishnaswamy, R. Messier, C. S. Wu, S. B. McLane, and T. T. Tsong, "Atom probe analysis of rf-sputtered a-Si:H films," J. Vac. Sci. Technol. 18, 309312 (1981) [doi:10.1116/1.570748]. 
[27] C. Lo, S. V. Krishnaswamy, R. Messier, K. R. P. M. Rao, and L. N. Mulay, "Mössbauer characterization of reactively sputtered iron nitride films," J. Vac. Sci. Technol. 18, 313-317 (1981) [doi:10.1116/1.570749].

[28] M. J. Kardauskas, S. J. Fonash, S. Ashok, S. V. Krishnaswamy, and R. Messier, "Sputtered iron oxide/silicon heterostructures," J. Vac. Sci. Technol. 18, 376-378 (1981) [doi:10.1116/1.570789].

[29] S. V. Krishnaswamy, L. L. Tongson, N. Said, and R. Messier, "Enhanced interdiffusion of $\mathrm{Cu}$ into rf-sputtered chromium oxide films," J. Vac. Sci. Technol. 18, 401-494 (1981) [doi:10.1116/1.570796].

[30] S. V. Krishnaswamy, R. Messier, P. Swab, L. L. Tongson, and K. Vedam, "Explosive crystallization of rf-sputtered amorphous CdTe films," J. Electronic Mater. 10, 433-443 (1981) [doi:10.1007/BF02654583].

[31] R. A. Roy, R. Messier, and J. M. Cowley, "Fine structure of gold particles in thin films prepared by metal-insulator co-sputtering," Thin Solid Films 79, 207-215 (1981) [doi:10.1016/0040-6090(81)90309-6].

[32] R. C. Ross and R. Messier, "Microstructure and properties of rf-sputtered amorphous hydrogenated silicon films," J. Appl. Phys. 52, 5329-5339 (1981) [doi:10.1063/1.329391].

[33] R. C. Ross and R. Messier, "Bombardment effects in a-Si:H sputtered films," AIP Conf. Proc. 73, 53-57 (1981) [doi:10.1063/1.33023].

[34] R. Messier, S. V. Krishnaswamy, and P. L. Walker, Jr., "Ion bombardment induced cone formation on glassy carbon and graphite surfaces," Carbon 20, 29-33 (1982) [doi:10.1016/0008-6223(82)90070-7].

[35] L. R. Gilbert, R. Messier, and R. Roy, "Bulk crystalline $\mathrm{BaPb}_{3 / 4} \mathrm{Bi}_{1 / 4} \mathrm{O}_{3}$ : A ceramic superconductor," Mater. Res. Bull. 17, 467-472 (1982) [doi:10.1016/00255408(82)90101-5].

[36] R. C. Ross, I. S. T. Tsong, R. Messier, W. A. Lanford, and C. Burman, "Quantification of hydrogen in a-Si:H by ir spectrometry, ${ }^{15} \mathrm{~N}$ nuclear reaction and SIMS," J. Vac. Sci. Technol. 20, 406-409 (1982) [doi:10.1116/1.571478].

[37] R. A. Roy, R. Messier, S. V. Krishnaswamy, and R. Roy, "Rapid solidification by rf-sputtering in the Mg-Zn-O system," in Advances in Ceramics, Vol. 4, J.H. Simons, D.R. Uhlmann, and G.H. Beall, Eds., 244-248, American Ceramic Society, Columbus, OH, USA (1982).

[38] R. Messier and R. C. Ross, "Evolution of microstructure in amorphous hydrogenated silicon," J. Appl. Phys. 53, 6220-6225 (1982) [doi:10.1063/1.331536].

[39] L. N. Mulay, S. V. Krishnaswamy, C. Lo, K. R. P. M. Rao, and R. Messier, "Mössbauer spectra of sputtered catalytically active Fe-N phases," Proc. Ind. Nat. Sci. Acad. S-16, 460-462 (1982).

[40] M. S. Barger, S. V. Krishnaswamy, and R. Messier, "The cleaning of daguerreotypes: I. Physical sputter cleaning, a new technique," in AIC Preprints, 9-20, American Institute for Conservation of Historic Works, Washington, DC, USA (1982).

[41] M. S. Barger, R. Messier, and W. B. White, "A physical model for the daguerreotype," Photograph. Sci. Eng. 26, 285-291 (1982).

[42] J. S. Lannin, L. J. Pilione, S. T. Kshirsagar, R. Messier, and R. C. Ross, "Variable structural order in amorphous silicon," Phys. Rev. B 26, 3506-3509 (1982) [doi:10.1103/PhysRevB.26.3506].

[43] R. Messier, "Microstructure-property relations in sputtered films," in Proc. DARPA Wkshp. Diamond-Like Carbon Coatings, B. Bendow, Ed., 224-243, Albuquerque, NM, USA (1982). 
[44] M. S. Barger, S. V. Krishnaswamy, and R. Messier, "The cleaning of daguerreotypes. Comparison of cleaning methods," J. Am. Inst. Conserv. 22, 13-24 (1982).

[45] R. C. Ross and R. Messier, "Reactive sputtering of amorphous silicon in Ne, $\mathrm{Ar}$ and Kr," J. Appl. Phys. 54, 5744-5749 (1983) [doi:10.1063/1.331797].

[46] R. A. Roy, R. Messier, and S. V. Krishnaswamy, "Preparation and properties of r.f.-sputtered polymer-metal thin films," Thin Solid Films 109, 27-35 (1983) [doi:10.1016/0040-6090(83)90028-7].

[47] M. S. Barger, R. Messier, and W. B. White, "Gilding and sealing daguerreotypes," Photograph. Sci. Eng. 27, 141-146 (1983).

[48] M. S. Barger, R. Messier, and W. B. White, "Daguerreotype display," Picturescope 31(2), 57-48 (1983).

[49] R. C. Ross and R. Messier, "The effects of hydrogen partial pressure on reactively sputtered amorphous silicon," J. Appl. Phys. 56, 347-351 (1984) [doi:10.1063/1.333970].

[50] R. Messier, A. P. Giri, and R. A. Roy, "Revised structure zone model for thin film physical structure," J. Vac. Sci. Technol. A 2, 500-503 (1984) [doi:10.1116/1.572604].

[51] R. A. Roy and R. Messier, "Preparation-physical structure relations in $\mathrm{SiC}$ sputtered film," J. Vac. Sci. Technol. A 2, 312-315 (1984) [doi:10.1116/1.572590].

[52] A. P. Giri and R. Messier, "Physical structure and the electrochromic effect in tungsten oxide films," MRS Symp. Proc. 24, 221-227 (1984).

[53] M. S. Barger, R. Messier, and W. B. White, "Nondestructive assessment of daguerreotype image quality by diffuse reflectance spectroscopy," Studies Conserv. 29, 84-86 (1984).

[54] R. Messier and D. J. Kester, "Anisotropic etching during negative ion resputtering," Appl. Surf. Sci. 22/23, 111-117 (1985).

[55] J. E. Yehoda and R. Messier, "Are thin film physical structures fractals?" Appl. Surf. Sci. 22/23, 590-595 (1985).

[56] R. Messier and J. E. Yehoda, "Geometry of thin-film morphology," J. Appl. Phys. 58, 3739-3746 (1985) [doi:10.1063/1.335639].

[57] J. R. Blanco, R. Messier, K. Vedam, and P. J. McMarr, "Spectroscopic ellipsometry study of rf-sputtered a-Ge films," MRS Symp. Proc. 38, 301-307 (1985).

[58] R. A. Roy and R. Messier, "Evolutionary growth development in SiC sputtered Films," MRS Symp. Proc. 38, 363-370 (1985).

[59] R. Messier and J. E. Yehoda, "Morphology of ballistically aggregated surface deposits," in Fractal Aspects of Materals; Extended Abstracts, R. B. Laibowitz, B. B. Mandelbrot, and D. E. Passoja, Eds., 123-125, Materials Research Society, Pittsburgh, PA, USA (1985).

[60] N. S. Holter, A. Lakhtakia, V. K. Varadan, V. V. Varadan, and R. Messier, "On a new class of planar fractals: the Pascal-Sierpinski gaskets," J. Phys. A: Math. Gen. 19, 1753-1759 (1986) [doi:10.1088/0305-4470/19/9/047].

[61] R. Messier, "Toward quantification of thin film morphology," J. Vac. Sci. Technol. A 4, 490-495 (1986) [doi:10.1116/1.573866].

[62] D. J. Kester and R. Messier, "Predicting negative ion resputtering in thin films," $J$. Vac. Sci. Technol. A 4, 496-499 (1986) [doi:10.1116/1.573867].

[63] J. R. Blanco, P. J. McMarr, J. E. Yehoda, K. Vedam, and R. Messier, "Density of amorphous germanium films by spectroscopic ellipsometry," J. Vac. Sci. Technol. $A$ 4, 577-582 (1986) [doi:10.1116/1.573851]. 
[64] A. Lakhtakia, N. S. Holter, R. Messier, V. K. Varadan, and V. V. Varadan, "On the spatial Fourier transforms of the Pascal-Sierpinski gaskets," J. Phys. A: Math. Gen. 19, 3147-3152 (1986) [doi:10.1088/0305-4470/19/15/035].

[65] A. Lakhtakia, R. Messier, V. K. Varadan, and V. V. Varadan, "Use of combinatorial algebra for diffusion on fractals," Phys. Rev. A 34, 2501-2504 (1986) [doi:10.1103/PhysRevA.34.2501]; corrections: Phys. Rev. A 35, 1445 (1987) [doi:10.1103/ PhysRevA.35.1445].

[66] P. J. McMarr, J. R. Blanco, K. Vedam, R. Messier, and L. Pilione, "Thicknessdependent void fraction of rf-sputtered amorphous Ge films by spectroscopic ellipsometry," Appl. Phys. Lett. 49, 328-330 (1986) [doi:10.1063/1.97157].

[67] A. Lakhtakia, R. Messier, V. V. Varadan, and V. K. Varadan, "Self-similarity versus self-affinity: the Sierpinski gasket revisited," J. Phys. A: Math. Gen. 19, L985-L989 (1986) [doi:10.1088/0305-4470/19/16/007].

[68] A. Lakhtakia, R. Messier, V. V. Varadan, and V. K. Varadan, "Fractal dimension from the back-scattering cross section," J. Phys. A: Math. Gen. 20, 1615-1619 (1986) [doi:10.1088/0305-4470/20/6/042].

[69] A. Lakhtakia, R. Messier, V. V. Varadan, and V. K. Varadan, "Spatial convolution and the generation of clusters and generalized Cantor bars," Phys. Lett. A 118, 5458 (1986) [doi:10.1016/0375-9601(86)90646-8].

[70] J. E. Yehoda and R. Messier, "Quantitative analysis of thin film morphology evolution," Proc. SPIE 678, 32-40 (1986).

[71] A. R. Badzian, B. Simonton, T. Badzian, R. Messier, K. E. Spear, and R. Roy, "Vapor deposition synthesis of diamond films," Proc. SPIE 683, 127-138 (1986).

[72] R. Messier, "Characterization of morphology of thin films," J. Mater. Educ. 8, 737-763 (1986).

[73] A. Das and R. Messier, "Low permittivity $\mathrm{SiO}_{2}$ void nanocomposite films," MRS Symp. Proc. 72, 27-33 (1986).

[74] S. Ashok, K. Srikanth, A. R. Badzian, T. Badzian, and R. Messier, "Space-chargelimited current in thin-film diamond," Appl. Phys. Lett. 50, 763-765 (1987) [doi:10.1063/1.98038].

[75] A. Lakhtakia, V. V. Varadan, R. Messier, and V. K. Varadan, "On the symmetries of the Julia sets for the process $z \rightarrow z^{p}+c$," J. Phys. A: Math. Gen. 20, 35333535 (1987) [doi:10.1088/0305-4470/20/11/051].

[76] A. Lakhtakia, V. K. Varadan, R. Messier, and V. V. Varadan, "Generalisations and randomisation of the plane Koch curve," J. Phys. A: Math. Gen. 20, 3537-3541 (1987) [doi:10.1088/0305-4470/20/11/052].

[77] A. Lakhtakia, R. Messier, V. K. Varadan, and V. V. Varadan, "Fractal structures derivable from the generalisations of the Pascal triangle," J. Phys. A: Math. Gen. 20, L735-L738 (1987) [doi:10.1088/0305-4470/20/11/011].

[78] L. J. Pilione, K. Vedam, J. E. Yehoda, R. Messier, and P. J. McMarr, "Thickness dependence of optical gap and void fraction for sputtered amorphous germanium," Phys. Rev. B 35, 9368-9371 (1987) [doi:10.1103/PhysRevB.35.9368].

[79] B. Yang, L. J. Pilione, J. E. Yehoda, K. Vedam, and R. Messier, "Nonuniformity in void concentration between the initial and final growth stage of sputtered a-Ge films studied using spectroscopic ellipsometry," Phys. Rev. B 36, 6206-6208 (1987) [doi:10.1103/PhysRevB.36.6206].

[80] R. Messier, A. R. Badzian, T. Badzian, K. E. Spear, P. Bachmann, and R. Roy, "From diamond-like carbon to diamond coatings," Thin Solid Films 153, 1-9 (1987) [doi:10.1016/0040-6090(87)90164-7].

[81] B. Yang, B. L. Walden, R. Messier, and W. B. White, "Computer simulation of the cross-sectional morphology of thin films," Proc. SPIE 821, 68-76 (1987). 
[82] R. Messier, K. E. Spear, A. R. Badzian, and R. Roy, "The quest for diamond coatings," J. Metals 39, 8-11 (1987).

[83] A. I. D'Souza, M. G. Roe, P. E. Wigen, and R. Messier, "Picosecond recombination of photo-excited carriers in sputtered a-Si:H," Solid State Commun. 63, 863-865 (1987) [doi:10.1016/0038-1098(87)90902-1].

[84] A. Lakhtakia, R. Messier, V. K. Varadan, and V V. Varadan, "Fractal sequences derived from the self-similar extensions of the Sierpinski gasket," J. Phys. A: Math. Gen. 21, 1925-1928 (1988) [doi:10.1088/0305-4470/21/8/030].

[85] A. R. Badzian, T. Badzian, R. Roy, R. Messier, and K. E. Spear, "Crystallization of diamond crystals and films by microwave assisted CVD (Part II)," Mater. Res. Bull. 23, 531-548 (1988) [doi:10.1016/0025-5408(88)90161-4].

[86] J. E. Yehoda, B. Yang, K. Vedam, and R. Messier, "Investigation of the void structure in amorphous germanium thin films as a function of low-energy ion bombardment," J. Vac. Sci. Technol. A 6, $1631-1635$ (1988) [doi:10.1116/1.575341].

[87] G. Sh. Gildenblat, S. A. Grot, C. R. Wronski, A. R. Badzian, T. Badzian, and R. Messier, "Electrical characteristics of Schottky diodes fabricated using plasma assisted chemical vapor deposited diamond films," Appl. Phys. Lett. 53, 586-588 (1988) [doi:10.1063/1.99865].

[88] K. Srikanth, S. Ashok, A. Badzian, T. Badzian, and R. Messier, "Electrical conduction in thin film diamond," Thin Solid Films 164, 187-190 (1988) [doi:10.1016/0040-6090(88)90132-0].

[89] K. E. Spear, M, Frenklach, A. Badzian, T. Badzian, and R. Messier, "Vapor deposition of crystalline diamond," Ceram. Eng. Sci. Proc. 9, 1095-1102 (1988).

[90] P. K. Bachmann and R. Messier, "Diamond," in McGraw-Hill Yearbook of Science and Technology 1989, 101-103, McGraw-Hill, New York, NY, USA (1988).

[91] A. Lakhtakia, R. Messier, V. V. Varadan, and V. K. Varadan, "Incommensurate numbers, continued fractions and fractal immittances," Z. Naturforsch. A 43, 943955 (1988).

[92] W. Zhu, A. R. Badzian, and R. Messier, "Structural imperfections in CVD diamond films," J. Mater. Res. 4, 659-663 (1989) [doi:10.1557/JMR.1989.0659].

[93] M. C. Hicks, C. R. Wronski, S. A. Grot, G. Sh. Gilenblat, A. R. Badzian, T. Badzian, and R. Messier, "The barrier height of Schottky diodes with a chemicalvapor-deposited diamond base," J. Appl. Phys. 65, 2139-2141 (1989) [doi:10.1063/1.342864].

[94] P. K. Bachmann and R. Messier, "Emerging diamond technology," Chem. Eng. News 67(20), 24-39 (1989).

[95] W. Piekarczyk, R. Roy, and R. Messier, "Application of thermodynamics to the examination of the diamond CVD process from hydrocarbon-hydrogen mixtures," J. Cryst. Growth 98, 765-776 (1989) [doi:10.1016/0022-0248(89)90316-3].

[96] Y. Liou, A. Inspektor, R. Weimer, and R. Messier, "Low-temperature diamond deposition by microwave plasma-enhanced chemical vapor deposition," Appl. Phys. Lett. 55, 631-633 (1989) [doi:10.1063/1.101807].

[97] Y. Liou, A. Inspektor, D. Knight, R. Weimer, D. Pickrell, A. Badzian, and R. Messier, "Low temperature diamond deposition on glass," Proc. SPIE 1146, 12-20 (1989).

[98] A. Inspektor, Y. Liou, T. McKenna, and R. Messier, "Plasma CVD diamond deposition in C-H-O systems," Surf. Coat. Technol. 39-40, 211-221 (1989) [doi:10.1016/0257-8972(89)90055-8].

[99] R. W. Collins, Y. Cong, Y.-T. Kim, K. Vedam, Y. Liou, A. Inspektor, and R. Messier, "Real-time and spectroscopic ellipsometry characterization of diamond 
and diamond-like carbon," Thin Solid Films 181, 565-578 (1989) [doi:10.1016/0040-6090(89)90525-7].

[100] W. A. Yarbrough, A. Inspektor, and R. F. Messier, "The chemical vapor deposition of diamond," Mater. Sci. Forum 52-53, 151-174 (1989).

[101] G. L. Huffman, D. E. Fahnline, R. Messier, and L. J. Pilione, "Stress dependence of reactively sputtered aluminum nitride thin films on sputtering parameters," $J$. Vac. Sci. Technol. A 7, 2252-2255 (1989) [doi:10.1116/1.575923].

[102] W. Zhu, C. A. Randall, A. R. Badzian, and R. Messier, "Graphite formation in diamond film deposition," J. Vac. Sci. Technol. A 7, 2315-2324 (1989) [doi:10.1116/1.575935].

[103] D. E. Fahnline, B. Yang, K. Vedam, R. Messier, and L. J. Pilione, "Intrinsic stress in a-Ge films deposited by rf-magnetron sputtering," MRS Symp. Proc. 130, 355360 (1989).

[104] T. T. Tsong, L. X. Li, S. D. Chi, Y. Liou, and R. Messier, "Dynamical behavior of platinum and gold surfaces and thin films," Thin Solid Films 172, L91-L96 (1989) [doi:10.1016/0040-6090(89)90659-7].

[105] A. Lakhtakia and R. Messier, "Self-similar sequences and chaos from Gauss sums," Comput. Graphics 13, 59-62 (1989) [doi:10.1016/0097-8493(89)90038-1].

[106] R. Messier and W. A. Yarbrough, "Preparation of diamond by chemical vapor deposition," AIP Physics Today, S65-S66 (January 1989).

[107] Y. Liou, R. Weimer, D. Knight, and R. Messier, "Effect of oxygen in diamond deposition at low substrate temperatures," Appl. Phys. Lett. 56, 437-439 (1990) [doi:10.1063/1.102758].

[108] G. Sh. Gildenblat, S. A. Grot, C. W. Hatfield, C. R. Wronski, A. R. Badzian, T. Badzian, and R. Messier, "High temperature Schottky diodes with boron-doped homoepitaxial diamond base," Mater. Res. Bull. 25, 129-134 (1990) [doi:10.1016/0025-5408(90) 90172-X].

[109] J. T. Glass, R. Messier, and N. Fujimori, Eds., Diamond, Silicon Carbide, and Related Wide Bandgap Semiconductors, Materials Research Society, Pittsburgh, PA, USA (1990).

[110] S. A. Grot, G. Sh. Gildenbalt, C. W. Hatfield, C. R. Wronski, A. R. Badzian, T. Badzian, and R. Messier, "The effect of surface treatment on the electrical properties of metal contacts to boron-doped homoepitaxial diamond film," IEEE Electron Dev. Lett. 11, 100-102 (1990) [doi:10.1109/55.46942].

[111] W. A. Yarbrough and R. Messier, "Current issues and problems in the chemical vapor deposition of diamond," Science 247, 688-696 (1990) [doi:10.1126/science. 247.4943. 688].

[112] R. Messier, J. E. Yehoda, and L. J. Pilione, "Ion-surface interactions: General understandings," in Handbook of Plasma Processing Technology, S. M. Rossnagel, J. J. Cuomo and W. D. Westwood, Eds., 448-465, Noyes Publications, Norwich, NY, USA (1990).

[113] W. Zhu, A. Inspektor, A. R. Badzian, T. McKenna, and R. Messier, "Effects of noble gases on diamond deposition from methane-hydrogen microwave plasmas," J. Appl. Phys. 68, 1489-1496 (1990) [doi:10.1063/1.346679].

[114] Y. Liou, A. Inspektor, R. Weimer, D. Knight, and R. Messier, "Oxygen effect in diamond deposition at low temperatures," MRS Symp. Proc. 162, 109-114 (1990).

[115] G. Sh. Gildenblat, S. A. Grot, C. W. Hatfield, C. R. Wronski, A. R. Badzian, T. Badzian, and R. Messier, "Electrical properties of homoepitaxial diamond films," MRS Symp. Proc. 162, 297-302 (1990).

[116] K. Srikanth S. Ashok, W. Zhu, A. Badzian, and R. Messier, "Deep level transient spectroscopy study of thin film diamond," MRS Symp. Proc. 162, 309-314 (1990). 
[117] Y. Liou, A. Inspektor, R. Weimer, D. Knight, and R. Messier, "The effect of oxygen in diamond deposition by microwave plasma enhanced chemical vapor deposition," J. Mater. Res. 5, 2305-2312 (1990) [doi:10.1557/JMR.1990.2305].

[118] X. H. Wang, L. Pilione, W. Zhu, W. Yarbrough, W. Drawl, and R. Messier, "Infrared optical properties of CVD diamond films," J. Mater. Res. 5, 2345-2350 (1990) [doi:10.1557/JMR.1990.2345].

[119] S. A. Grot, S. Lee, G. Sh. Gildenblat, C. W. Hatfield, C. R. Wronski, A. R. Badzian, T. Badzian, and R. Messier, "Rectification and internal photoemission in metal/CVD diamond and metal/CVD diamond/silicon structures," J. Mater. Res. 5, 2497-2501 (1990) [doi:10.1557/JMR.1990.2497].

[120] D. J. Pickrell, W. Zhu, A. R. Badzian, R. Messier, and R. E. Newnham, "Downstream plasma-enhanced diamond film deposition," Appl. Phys. Lett. 56, 2010-2012 (1990) [doi:10.1063/1.103001].

[121] T. DebRoy, K. Tankala, W. Yarbrough, and R. Messier, "Role of heat transfer and fluid flow in the chemical vapor deposition of diamond," J. Appl. Phys. 68, 24242432 (1990) [doi:10.1063/1.346502].

[122] Y. Cong, I. An, R. W. Collins, K. Vedam, H. S. Witham, L. J. Pilione, and R. Messier, "Real-time spectroscopic ellipsometry for determination of the optical functions of ion-beam-deposited hydrogenated amorphous carbon," Thin Solid Films 193-194, 361-370 (1990) [doi:10.1016/S0040-6090(05)80046-X].

[123] W. Piekarczyk, R. F. Messier, R. Roy, and C. Engdahl, "Investigation of diamond deposition by chemical vapor transport with hydrogen," Proc. SPIE 1325, 30-40 (1990) [doi:10.1117/12.22440].

[124] X.-H. Wang, L. J. Pilione, W. Zhu, W. A. Yarbrough, W. R. Drawl, and R. F. Messier, "Infrared measurements of CVD diamond films," Proc. SPIE 1325, 160167 (1990) [doi:10.1117/12.22455].

[125] W. Zhu, A. R. Badzian, and R. F. Messier, "Morphological phenomena of CVD diamond (Part I)," Proc. SPIE 1325, 187-201 (1990) [doi:10.1117/12.22458].

[126] W. Piekarczyk, R. Messier, R. Roy, and C. Engdahl, "Diamond deposition by chemical vapor transport with hydrogen in a closed system," J. Cryst. Growth 106, 279-293 (1990) [doi:10.1016/0022-0248(90)90074-U].

[127] W. Zhu, R. F. Messier, and A. R. Badzian, "Morphological phenomena of CVD diamond (Part II)," Proc. SPIE 1534, 230-242 (1991) [doi:10.1117/12.48297].

[128] R. Messier, J. T. Glass, J. E. Butler, and R. Roy, Eds., New Diamond Science and Technology, Materials Research Society, Pittsburgh, PA, USA (1991).

[129] W. Zhu, X. H. Wang, D. Pickrell, A. R. Badzian, and R. Messier, "An investigation of the oxidation behavior of CVD diamond films," in New Diamond Science and Technology, R. Messier, J.T. Glass, J.E. Butler, and R. Roy, Eds., 821-826, Materials Research Society, Pittsburgh, PA, USA (1991).

[130] Y. Cong, R. W. Collins, Y. Liou, R. Messier, K. Vedam, G. F. Epps, and H. Windischmann, "Spectroscopic ellipsometry study of the optical properties of thin film diamond and diamond surfaces in real time during ion beam etching," in New Diamond Science and Technology, R. Messier, J. T. Glass, J. E. Butler, and R. Roy, Eds., 735-740, Materials Research Society, Pittsburgh, PA, USA (1991).

[131] D. Pickrell, W. Zhu, A. R. Badzian, R. E. Newnham, and R. Messier, "Nearinterface characterization of diamond films on silica and silicon," J. Mater. Res. 6, 1264-1277 (1991) [doi:10.1557/JMR.1991.1264].

[132] R. W. Collins, I. An, Y. Cong, A. R. Heyd, H. S. Witham, R. Messier, and K. Vedam, "Real time spectroscopic ellipsometry for non-invasive characterization of thin film growth and etching," in Nondestructive Characterization of Materials IV, R. E. Green and C. O. Ruud, Eds., 33-40, Plenum, New York, NY, USA (1991). 
[133] Y. Cong, R. W. Collins, R. Messier, K. Vedam, G. F. Epps, and H. Windischmann, "Characterization of ion beam-induced surface modification of diamond films by real time spectroscopic ellipsometry," J. Vac. Sci. Technol. A 9, 1123-1128 (1991) [doi:10.1116/1.577588].

[134] X.-Q. Yang, M. W. Ruckman, T. A. Skotheim, M. den Boer, Y. Zheng, A. R. Badzian, T. Badzian, R. Messier, and A. R. Srivatsa, "X-ray absorption study of diamond films grown by chemical vapor deposition," J. Vac. Sci. Technol. A 9, 1140-1144 (1991) [doi:10.1116/1.577591].

[135] R. A. Roy and R. Messier, "Quantitative analysis of thin film morphology evolution," in High Performance Ceramic Films and Coatings, P. Vincenzini, Ed., 367-380, Elsevier, Amsterdam, The Netherlands (1991).

[136] J. M. García-Ruiz, A. Lakhtakia, and R. Messier, "Does competition between growth elements eventually eliminate self-affinity?" Speculat. Sci. Technol. 15, 60-71 (1991).

[137] Y. Cong, I. An, H. V. Nguyen, K. Vedam, R. Messier, and R. W. Collins, "Real time monitoring of filament-assisted chemically vapor deposited diamond by spectroscopic ellipsometry," Surf. Coat. Technol. 49, 381-386 (1991) [doi:10.1016/0257-8972(91)90087-D].

[138] Y. Hayashi, W. Drawl, and R. Messier, "Temperature dependence of nucleation density of chemical vapor deposition diamond," Jpn. J. Appl. Phys. 31, L193-L196 (1992) [doi:10.1143/JJAP.31.L193].

[139] H. Witham, P. Chindaudom, R. Messier, and K. Vedam, "Morphology control of the electrochromic effect in tungsten oxide thin films," MRS Symp. Proc. 255, 275280 (1992).

[140] D. J. Kester and R. Messier, "Ion beam assisted deposition of cubic boron nitride thin films," MRS Symp. Proc. 235, 721-727 (1992).

[141] D. K. Sood, W. R. Drawl, and R. Messier, "The effect of carbon ion implantation on the nucleation of diamond on Ti-6Al-4V alloy," Surf. Coat. Technol. 51, 307312 (1992) [doi:10.1016/0257-8972(92)90255-9].

[142] A. M. Kazakos, D. E. Fahnline, R. Messier, and L. J. Pilione, "Compositional dependence of stress in silver copper alloys prepared by direct current magnetron sputtering," J. Vac. Sci. Technol. A 10, 3439-3444 (1992) [doi:10.1116/1.577799].

[143] A. M. Kazakos, D. E. Fahnline, R. Messier, and L. J. Pilione, "Compositional dependence of grain size in silver copper alloys prepared by direct current magnetron sputtering," J. Vac. Sci. Technol. A 10, 3445-3450 (1992) [doi:10.1116/1.577800].

[144] R. W. Collins, Y. Cong, H. V. Nguyen, I. An, K. Vedam, T. Badzian, and R. Messier, "Real time spectroscopic ellipsometry characterization of the nucleation of diamond by filament-assisted chemical vapor deposition," J. Appl. Phys. 71, 5287-5289 (1992) [doi:10.1063/1.350544].

[145] D. J. Kester and R. Messier, "Phase control of cubic boron nitride thin films," $J$. Appl. Phys. 72, 504-513 (1992) [doi:10.1063/1.351881].

[146] Y. Hayashi, W. Drawl, R. W. Collins, and R. Messier, "In-process ellipsometric monitoring of diamond film growth by microwave plasma enhanced chemical vapor deposition," Appl. Phys. Lett. 60, 2868-2870 (1992) [doi:10.1063/1.106827].

[147] H. S. Witham, P. Chindaudom, I. An, R. W. Collins, R. Messier, and K. Vedam, "Effect of preparation conditions on the morphology and electrochromic properties of amorphous tungsten oxide films," J. Vac. Sci. Technol. A 11, 1881-1887 (1993) [doi:10.1116/1.578517].

[148] I. An, R.W. Collins, H. V. Nguyen, K. Vedam, H. S. Witham, and R. Messier, "Hydrogen diffusion and reaction processes in thin films investigated by real time 
spectroscopic ellipsometry," Thin Solid Films 233, 276-280 (1993) [doi:10.1016/0040-6090(93)90107-Z].

[149] D. J. Kester and R. Messier, "Macro-effects of resputtering due to negative ion bombardment of growing thin films," J. Mater. Res. 8, 1928-1937 (1993) [doi:10.1557/JMR.1993.1928].

[150] D. J. Kester and R. Messier, "Micro-effects of resputtering due to negative ion bombardment of growing thin films," J. Mater. Res. 8, 1938-1957 (1993) [doi:10.1557/JMR.1993.1938].

[151] R. Messier, "Toward quantification of thin film morphology: Revisited," in Surface Disordering: Growth, Roughening and Phase Transitions, R. Jullien, J. Kertesz, P. Meakin, and D. E. Wolf, Eds., 85-90, Nova Science, Commack, NY, USA (1993).

[152] A. Lakhtakia and R. Messier, "Reflection at the Motohiro-Taga interface of two anisotropic materials with columnar microstructures," Opt. Eng. $\underline{\text { 33 }, ~ 2529-2534 ~}$ (1994) [doi:10.1117/12.177108].

[153] A. Lakhtakia and R. Messier, "The key to thin film HBMs: The Motohiro-Taga interface," Proc. Chiral '94, F. Mariotte and J-P. Parneix, Eds., 125-130, CEACESTA, Périgueux, France (1994).

[154] L. B. Hackenberger, L. J. Pilione, R. Messier, and G. P. Lamaze, "Effect of stoichiometry on the phases present in boron nitride thin films," J. Vac. Sci. Technol. A 12, 1569-1575 (1994) [doi:10.1116/1.579357].

[155] B. Hong, M. Wakagi, R. W. Collins, I. An, N. C. Engdahl, W. Drawl, and R. Messier, "Real-time spectroscopic ellipsometry studies of diamond film growth by microwave plasma-enhanced chemical vapour deposition," Diamond Relat. Mater. 3, 431-437 (1994) [doi:10.1016/0925-9635(94)90198-8].

[156] G. P. Lamaze, R. G. Downing, L. B. Hackenberger, L. J. Pilione, and R. Messier, "Analysis of cubic boron nitride thin films by neutron depth profiling," Diamond Relat. Mater. 3, 728-731 (1994) [doi:10.1016/0925-9635(94)90258-5].

[157] B. Hong, M. Wakagi, W. Drawl, R. Messier, and R. W. Collins, "Real time spectroellipsometry study of evolution of bonding in diamond thin films during nucleation and growth," Phys. Rev. Lett. 75, 1122-1125 (1995) [doi:10.1103/PhysRevLett.75.1122].

[158] M. Wakagi, B. Hong, H. V. Nguyen, R. W. Collins, W. Drawl, and R. Messier, "Characterization of substrate temperature and damage in diamond growth plasmas by multichannel spectroellipsometry," J. Vac. Sci. Technol. A 13, 19171923 (1995) [doi:10.1116/1.579680].

[159] L. B. Hackenberger, L. J. Pilione, and R. Messier, "Bombardment stabilization of cubic boron nitride," in Science and Technology of Thin Films, F. C. Matacotta and G. Ottaviani, Eds., 121-144, World Scientific, Singapore (1995).

[160] P. Keblinski, A. Maritan, R. Messier, F. Toigo, and J. R. Banavar, "Morphology of thin films," MRS Symp. Proc. 355, 71-76 (1995).

[161] D. S. Zhou, C. L. Chen, T. E. Mitchell, L. B. Hackenberger, and R. Messier, "Thin films of cubic boron nitride on silicon," Phil. Mag. Lett. 72, 163-166 (1995) [doi:10.1080/09500839508242447].

[162] S. G. Song, C. L. Chen, T. E. Mitchell, L. B. Hackenberger, and R. Messier, "Observation of the nanoscale epitaxial growth of diamond on Si (100) surface," $J$. Appl. Phys. 79, 1813-1815 (1996) [doi:10.1063/1.360975].

[163] P. Keblinski, A. Maritan, F. Toigo, R. Messier, and J. R. Banavar, "Continuum model for the growth of interfaces," Phys. Rev. E 53, 759-778 (1996) [doi:10.1103/PhysRevE.53.759]. 
[164] C. Wiemer, F. Lévy, and R. Messier, "Effect of ion collisions on Langmuir probe measurements in Ti-N deposition by unbalanced magnetron sputtering," J. Phys. D: Appl. Phys. 29, 99-104 (1996) [doi: 10.1088/0022-3727/29/1/018].

[165] C. Wiemer, F. Lévy, and R. Messier, "Stress dependence on ion bombardment in Ti-N thin films deposited by room temperature unbalanced magnetron sputtering," Proceedings ECASIA '95, H.J. Mathieu, B. Reihl, and D. Briggs, Eds., 779-782, Wiley, New York, NY, USA (1996).

[166] C. Wiemer, F. Lévy, and R. Messier, "Langmuir probe evaluation of ion bombardment during Ti-N growth by unbalanced magnetron sputtering," Thin Solid Films 281-282, 52-56 (1996) [doi:10.1016/0040-6090(96)08573-2].

[167] A. Lakhtakia, R. Messier, M. J. Brett, and K. Robbie, "Sculptured thin films (STFS) for optical, chemical and biological applications," Innovat. Mater. Res. 1, 165-176 (1996).

[168] A. Lakhtakia, R. Messier, K. Robbie, and M. J. Brett, "Sculptured thin filmsNanoengineered matter for optical and submillimeter wave applications," in Proc. 1996 Asia-Pacific Microw. Conf., R. S. Gupta, Ed., 1091-1094, New Delhi, India (1996).

[169] J. Lee, B. Hong, R. Messier, and R. W. Collins, "Real time spectroellipsometry for optimization of diamond film growth by microwave plasma-enhanced chemical vapor deposition from $\mathrm{CO} / \mathrm{H}_{2}$ mixtures," J. Appl. Phys. 80, 6489-6495 (1996) [doi:10.1063/1.363668].

[170] J. Lee, B. Hong, R. Messier, and R. W. Collins, "Nucleation and bulk film growth kinetics of nanocrystalline diamond prepared by microwave plasma-enhanced chemical vapor deposition on silicon substrates," Appl. Phys. Lett. 69, 1716-1718 (1996) [doi:10.1063/1.118007].

[171] J. Lee, R. W. Collins, and R. Messier, "Low temperature plasma process based on CO-rich $\mathrm{CO} / \mathrm{H}_{2}$ mixtures for high rate diamond film deposition," Appl. Phys. Lett. 70, 1527-1529 (1997) [doi:10.1063/1.118607].

[172] B. Hong, J. Lee, R. W. Collins, Y. Kuang, W. Drawl, R. Messier, T. T. Tsong, and Y. E. Strausser, "Effects of processing conditions on the growth of nanocrystalline diamond thin films: real time spectroscopic ellipsometry studies," Diamond Relat. Mater. 6, 55-80 (1997) [doi:10.1016/S0925-9635(96)00591-2].

[173] J. Lee, R. W. Collins, B. Hong, R. Messier, and Y. E. Strausser, "Analysis of the growth processes of plasma-enhanced chemical vapor deposited diamond films from $\mathrm{CO} / \mathrm{H}_{2}$ and $\mathrm{CH}_{4} / \mathrm{H}_{2}$ mixtures using real-time spectroellipsometry," J. Vac. Sci. Technol. A 15, 1929-1936 (1997) [doi:10.1116/1.580661].

[174] R. Messier, T. Gehrke, C. Frankel, W. Otaño, V. C. Venugopal, and A. Lakhtakia, "Engineered sculptured nematic thin films," J. Vac. Sci. Technol A 15, 2148-2152 (1997) [doi:10.1116/1.580621].

[175] P. I. Rovira, R. A. Yarussi, R. W. Collins, R. Messier, V. C. Venugopal, A. Lakhtakia, K. Robbie, and M. J. Brett, "Transmission ellipsometry of a thin-film helicoidal bianisotropic medium," Appl. Phys. Lett. 71, 1180-1182 (1997) [doi:10.1063/1.119618].

[176] A. Rodriguez-Navarro, W. Otaño-Rivera, J. M. García-Ruiz, R. Messier, and L. J. Pilione, "Preparation of highly-oriented polycrystalline AIN thin films on glass, deposited at oblique-angle incidence," J. Mater. Res. 12, 1689-1692 (1997) [doi:10.1557/JMR.1997.0232].

[177] A. Rodriguez-Navarro, W. Otaño-Rivera, J. M. García-Ruiz, and R. Messier, "Development of preferred orientation in polycrystalline AIN thin films deposited by rf sputtering system at low temperature," J. Mater. Res. 12, 1850-1855 (1997) [doi:10.1557/JMR.1997.0254]. 
[178] T. Unagami, A. Lousa, and R. Messier, "Silicon thin film with columnar structure formed by RF diode sputtering," Jpn. J. Appl. Phys. 36, L737-L739 (1997) [doi:10.1143/JJAP.36.L737].

[179] A. Lakhtakia and R. Messier. "Sculptured thin films-I. Concepts," Mater. Res. Innovat. 1, 145-148 (1997) [doi:10.1007/s100190050032].

[180] W. Otaño-Rivera, L. J. Pilione, and R. Messier, "Pressure dependence of the negative bias voltage for stabilization of cubic boron nitride thin films deposited by sputtering," Appl. Phys. Lett. 72, 2523-2525 (1998) [doi:10.1063/1.121407].

[181] A. Rodriguez-Navarro, W. Otaño-Rivera, R. Messier, L. J. Pilione, and J. M. García-Ruiz, "Control of the preferred orientation of AlN thin films by collimated sputtering," J. Vac. Sci. Technol A 16. 1244-1246 (1998) [doi:10.1116/1.581267].

[182] W. Otaño-Rivera, L. J. Pilione, J. Zapien, and R. Messier, "Cubic boron nitride thin film deposition by unbalanced magnetron sputtering and dc pulsed substrate biasing," J. Vac. Sci. Technol. A 16, 1331-1335 (1998) [doi:10.1116/1.581146].

[183] J. Lee, B. Hong, R. Messier and R. W. Collins, "Application of real-time Spectroscopic ellipsometry for the development of low-temperature diamond film growth processes," Thin Solid Films 313-314, 506-510 (1998) [doi:10.1016/S0040-6090(97)00874-2].

[184] P. I. Rovira, R. A. Yarussi, R. W. Collins, V. C. Venugopal, A. Lakhtakia, R. Messier, K. Robbie, and M. J. Brett, "Rotating-compensator multichannel transmission ellipsometry of a thin-film helicoidal bianisotropic medium," Thin Solid Films 313-314, 373-378 (1998) [doi:10.1016/S0040-6090(97)00849-3].

[185] A. Lakhtakia, V. C. Venugopal, and R. Messier, "Dielectric sculptured nematic thin-film bilayers with S-shaped morphology as rugate-like filters," Microwave Opt. Technol. Lett. 18, 147-149 (1998) [doi:10.1002/(SICI)1098-2760(19980605) 18:2<147::AID-MOP17>3.0.CO;2-4].

[186] P. D. Sunal, A. Lakhtakia, and R. Messier, "Simple model for dielectric thin-film helicoidal bianisotropic media," Opt. Commun. 158, 119-126 (1998) [doi:10.1016/S0030-4018(98)00447-7].

[187] A. Lakhtakia and R. F. Messier, Eds., Engineered Nanostructural Films and Materials, SPIE, Bellingham, WA, USA (1999).

[188] R. Messier and A. Lakhtakia, "Sculptured thin films-II. Experiments and applications," Mater. Res. Innovat. 2, 217-222 (1999) [doi:10.1007/s100190050088].

[189] I. Hodgkinson, Q. H. Wu, A. Lakhtakia, and R. Messier, "Linear and circular polarization filters using sculptured thin films," OSA Opt. Photon. News 10(12), 30-31 (1999).

[190] R. Messier, P. D. Sunal, and V. C. Venugopal, "Evolution of sculptured thin films," Proc. SPIE 3790, 133-141 (1999) [doi:10.1117/12.351244].

[191] A. Lakhtakia, W. S. Weiglhofer, and R. F. Messier, Eds., Complex Mediums, SPIE, Bellingham, WA, USA (2000).

[192] V. C. Venugopal, A. Lakhtakia, R. Messier, and J.-P. Kucera, "Low-permittivity nanocomposite materials using sculptured thin film technology," J. Vac. Sci. Technol. B 18, 32-36 (2000) [doi:10.1116/1.591146].

[193] R. Messier, V. C. Venugopal, and P. D. Sunal, "Origin and evolution of sculptured thin films," J. Vac. Sci. Technol. A 18, 1538-1545 (2000) [doi:10.1116/1.582381].

[194] R. W. Collins, P. I. Rovira, A. S. Ferlanto, J. Koh, I. An, J. A. Zapien, R. Messier, and C. R. Wronski, "Real time characterization of non-ideal surfaces and thin film growth by advanced ellipsometric techniques," MRS Symp. Proc. 569, 43-58 (2000).

[195] J. A. Zapien, R. W. Collins, and R. Messier, "Extension of multichannel spectroscopic ellipsometry in to the ultraviolet for real time characterization of the 
growth of wide band-gap materials form 1.5 to $6.5 \mathrm{eV}$," MRS Symp. Proc. 569, 71 $76(2000)$.

[196] J. A. Zapien, R. W. Collins, and R. Messier, "Real-time spectroscopic ellipsometry from 1.5 to $6.5 \mathrm{eV}$," Thin Solid Films 364, 16-21 (2000) [doi:10.1016/S00406090(99)00916-5].

[197] R. W. Collins, J. Koh, H. Fujiwara, P. I. Rovira, A. S. Ferlauto, J. A. Zapien, C. R. Wronski, and R. Messier, "Recent progress in thin film growth analysis by multichannel spectroscopic ellipsometry," Appl. Surf. Sci. 154-155, 217-228 (2000) [doi:10.1016/S0169-4332(99)00482-1].

[198] J. A. Zapien, R. W. Collins, and R. Messier, "Multichannel ellipsometer for real time spectroscopy of thin film deposition from 1.5 to $6.5 \mathrm{eV}$," Rev. Sci. Instrum. 71, 3451-3460 (2000) [doi:10.1063/1.1288260].

[199] R. Knepper and R. Messier, "Morphology and mechanical properties of oblique angle columnar thin films," Proc. SPIE 4097, 291-298 (2000) [doi:10.1117/12.390588].

[200] A. Rodriguez-Navarro, C. Jiménez-Lopez, J. M. García-Ruiz, and R. Messier, "Importance of electrostatic interactions between calcite surfaces and proteins," MRS Symp. Proc. 599, 353-359 (2000).

[201] R. Messier and S. Trolier-McKinstry, "Processing of ceramic thin films," in Encyclopedia of Materials: Science and Technology, Vol. 10, K. H. J. Buschow, R. W. Cahn, M. C. Flemings, B. Ilschner, E. J. Kramer, and S. Mahajan, Eds., 93069313, Pergamon/Elsevier Science, Amsterdam, The Netherlands (2001).

[202] J. A. Zapien, R. W. Collins, and R. Messier, "Multichannel ellipsometry from 1.5 to $6.5 \mathrm{eV}$ for real time characterization of wide band gap materials: phase identification in boron nitride thin films," Diamond Relat. Mater. 10, 1304-1310 (2001) [doi:10.1016/S0925-9635(00)00600-2].

[203] J. A. Zapien, R. W. Collins, and R. Messier, "Ultraviolet-extended real-time spectroscopic ellipsometry for characterization of phase evolution in BN thin Films," Appl. Phys. Lett. 78, 1982-1984 (2001) [doi:10.1063/1.1358367].

[204] R. Knepper and R. Messier, "Thin film morphology at low adatom mobility," Proc. SPIE 4467, 87-101 (2001) [doi:10.1117/12.432957].

[205] A. Lakhtakia and R. Messier, "Sculptured thin films," OSA Opt. Photon. News 12(9), 26-31 (2001).

[206] J. A. Zapien, R. W. Collins, L. J. Pilione, and R. Messier, "Characterization of wide bandgap thin film growth using UV-extended Real time spectroscopic ellipsometry: Applications to cubic boron nitride," J. Wide Band-Gap Mater. 9, 191-206 (2002) [doi:10.1106/152451102024505]

[207] R. Messier, A. Lakhtakia, V. C. Venugopal, and P. D. Sunal, "Sculptured thin films: Engineered nanostructural materials," Vac. Technol. Coat. 2(10), 40-47 (2001).

[208] J.A. Zapien, R. W. Collins, and R. Messier, "Characterization of cubic boron nitride growth using UV-extended real-time spectroscopic ellipsometry: Effect of plasma additions and dynamic substrate bias steps," J. Vac. Sci. Technol. 20, 13951407 (2002) [doi:10.1116/1.1486226].

[209] P. F. Carcia, R. S. McLean, M. H. Reilly, Z. G. Li, L. J. Pilione, and R. Messier, "Low-stress indium-tin-oxide thin films $\mathrm{rf}$ magnetron sputtered on polyester substrates," Appl. Phys. Lett. 81, 1800-1802 (2002) [doi:10.1063/1.1504874].

[210] F. Wang, A. Lakhtakia, and R. Messier, "Coupling of Raleigh-Wood anomalies and the circular Bragg phenomenon in slanted chiral sculptured thin films," Eur. Phys. J. Appl. Phys. 20, 91-103 (2002) [doi:10.1051/epjap:2002079]; corrections: Eur. Phys. J. Appl. Phys. 24, 91 (2003) [doi:10.1051/epjap:2003069]. 
[211] F. Wang, A. Lakhtakia, and R. Messier, "Towards piezoelectrically tunable chiral sculptured thin films," Sens. Actuat. A: Phys. 102, 31-35 (2002) [doi:10.1016/S0924-4247(02)00271-6].

[212] F. Wang, A. Lakhtakia, and R. Messier, "Piezoelectric control of lasing in polymeric chiral sculptured thin films," Proc. SPIE 4806, 258-263 (2002) [doi:10.1117/12.472992].

[213] F. Wang, A. Lakhtakia, and R. Messier, "On piezoelectric control of the optical response of sculptured thin films," J. Modern Opt. 50, 239-249 (2003) [doi:10.1080/09500340308235173].

[214] A. Lakhtakia and R. Messier, "Sculptured thin films," in Perspectives in Engineering Optics, K. Singh and V. K. Rastogi, Eds., 217-224, Anita Publications, New Delhi, India (2003).

[215] P. F. Carcia, R. S. McLean, M. H. Reilly, Z. G. Li, L. J. Pilione, and R.F. Messier, "Influence of energetic bombardment on stress, resistivity, and microstructure of indium tin oxide films grown by radio frequency magnetron sputtering on flexible polyester substrates," J. Vac. Sci. Technol. A 21, 745-751 (2003) [doi:10.1116/1.1566789].

[216] P. F. Carcia, R. S. McLean, M. H. Reilly, Z. G. Li, L. J. Pilione, and R. Messier, "Resistivity and microstructure issues in indium tin oxide based films grown by $\mathrm{rf}$ magnetron sputtering on flexible polyester substrates," Vac. Technol. Coat. 5(8), 44-49 (2003).

[217] P. F. Carcia, R. S. McLean, M. H. Reilly, Z. G. Li, L. J. Pilione, and R. Messier, "Resistivity and microstructure issues in indium tin oxide based films grown by rf magnetron sputtering on flexible polyester substrates," Proc. Soc. Vac. Coat. 46, 195-199 (2003).

[218] R. Messier and A. Lakhtakia, "The past, the present, and the future of sculptured thin films," in Introduction to Complex Mediums for Optics and Electromagnetics, W. S. Weiglhofer and A. Lakhtakia, Eds., 447-478, SPIE Press, Bellingham, WA, USA (2003).

[219] N. J. Podraza, C. Chen, I. An, G. M. Ferreira, P. I. Rovira, R. Messier, and R. W. Collins, "Analysis of the optical properties and structure of sculptured thin films from spectroscopic Mueller matrix ellipsometry," Thin Solid Films 451, 571-575 (2004) [doi:10.1016/j.tsf.2003.11.219].

[220] M. W. Horn, M. D. Pickett, R. Messier, and A. Lakhtakia, "Blending of nanoscale and microscale in uniform large-scale sculptured thin-film architectures," Nanotechnology 15, 303-310 (2004) [doi:10.1088/0957-4484/15/3/013].

[221] A. Lakhtakia and R. Messier, "Sculptured thin films," in Nanometer Structures: Theory, Modeling, and Simulation, A. Lakhtakia, Ed., 5-44, SPIE Press, Bellingham, WA, USA (2004).

[222] W. Otaño-Rivera, R. Messier, L. J. Pilione, J. J. Santiago, and G. Lamaze, "Effect of $\mathrm{Al}$ additions and $\mathrm{AlN}$ interlayers on the stabilization of $\mathrm{cBN}$ sputtered thin films," Diamond Relat. Mater. 13, 1690-1696 (2004) [doi:10.1016/j.diamond.2004.02.005].

[223] M. W. Horn, M. D. Pickett, R. Messier, and A. Lakhtakia, "Selective growth of sculptured nanowires on microlithographic lattices," J. Vac. Sci. Technol. B 22, 3426-3430 (2004) [doi:10.1116/1.1824052].

[224] A. Lakhtakia and R. Messier, Sculptured Thin Films: Nanoengineered Morphology and Optics, SPIE Press, Bellingham, WA, USA (2005).

[225] Q. He, C. Li, C. Frankel, L. Pilione, B. Drawl, F. Lu, and R. Messier, "Deposition of c-BN on Si substrates coated with diamond thin films," Thin Solid Films 474, 96-102 (2005) [doi:10.1016/j.tsf.2004.08.018]. 
[226] P. Sunal, R. Messier, and M. W. Horn, "Reactive co-deposition of $\operatorname{TiN}_{x} / \operatorname{SiN}_{x}$ nanocomposites using pulsed direct current magnetron sputtering," Thin Solid Films 515, 2185-2191 (2006) [doi:10.1016/j.tsf.2006.07.006].

[227] J. RaviPrakash, A. H. McDaniel, M. Horn, L. Pilione, P. Sunal, R. Messier, R. T. McGrath, and F. K. Schweighardt, "Hydrogen sensors: Role of palladium thin film morphology," Sens. Actuat. B: Chem. 120, 439-446 (2007) [doi:10.1016/j.snb.2006.02.050].

[228] R. Messier, "The nano-world of thin films," J. Nanophoton. 2, 021995 (2008) [doi: $10.1117 / 1.3000671]$. 